Abstracta Iranica

Revue bibliographique pour le domaine irano-aryen

Volume 37-38-39 | 2018

Comptes rendus des publications de 2014-2016

\title{
Sanaz Fotouhi. The Literature of the Iranian Diaspora: Meaning and Identity Since the Islamic Revolution
}

\section{Laetitia Nanquette}

\section{(2) OpenEdition}

1 Journals

\author{
Electronic version \\ URL: http://journals.openedition.org/abstractairanica/43798 \\ DOI: 10.4000/abstractairanica.43798 \\ ISBN: 1961-960X \\ ISSN: 1961-960X \\ Publisher: \\ CNRS (UMR 7528 Mondes iraniens et indiens), Éditions de l'IFRI
}

Electronic reference

Laetitia Nanquette, « Sanaz Fotouhi. The Literature of the Iranian Diaspora: Meaning and Identity Since the Islamic Revolution », Abstracta Iranica [Online], Volume 37-38-39 | 2018, document 1, Online since 30 December 2018, connection on 27 September 2020. URL : http://journals.openedition.org/ abstractairanica/43798; DOI : https://doi.org/10.4000/abstractairanica.43798

This text was automatically generated on 27 September 2020

Tous droits réservés 


\title{
Sanaz Fotouhi. The Literature of the Iranian Diaspora: Meaning and Identity Since the Islamic Revolution
}

\author{
Laetitia Nanquette
}

\section{REFERENCES}

Sanaz Fotouhi. The Literature of the Iranian Diaspora: Meaning and Identity Since the Islamic Revolution. London: I.B. Tauris, 2015, 256 p., ill., ISBN: 9781780767284

1 The literature on hyphenated writers of the Iranian diaspora has grown exponentially in recent years, and this monograph is an interesting new addition to the field. It offers a nuanced and comprehensive overview of the literature from this diaspora written in English. Focusing on texts by Iranian-Americans, it presents a careful analysis of a large number of works that deal with issues of migration, identity, belonging and inbetweenness. It engages with theoretical reflections on Iranian diasporic writing and the use of a new language, English, rather than Persian, and discusses the contribution of this literature to postcolonial and world literature debates. The book is original in its analysis of texts by Iranian men, where much of the recent scholarship has focused on Iranian women writers, especially on the writers of memoirs. As an Iranian-Australian, the author inscribes herself in the book with subtle personal notes of her experiences as a member of this Iranian literary diaspora. 


\section{AUTHORS}

\section{LAETITIA NANQUETTE}

University of New South Wales, Sydney 